\title{
Phylogenetic relationships in Tunisian date-palm (Phoenix dactylifera L.) germplasm collection using DNA amplification fingerprinting
}

\author{
Mokhtar TRIFI $^{\mathrm{a} *}$, Abdelmajid RHOUMA ${ }^{\mathrm{b}}$, Mohamed MARRAKCHI $^{\mathrm{a}}$ \\ a Laboratoire de Génétique Moléculaire, Immunologie et Biotechnologie, Département de Biologie, \\ Faculté des Sciences de Tunis, Campus Universitaire, 2092 El Manar, Tunis, Tunisia \\ ${ }^{\mathrm{b}}$ Centre de Recherches Phoénicicoles, INRA, Degache, Tunisia
}

(Received 8 October 1999; accepted 10 April 2000)

\begin{abstract}
DNA amplification fingerprinting analysis has been performed to investigate phylogenetic relationships among a collection of Tunisian date-palm varieties. A set of universal decamer primers was used to generate DNA fragments from several different varieties in order to evaluate genetic distances between the tested varieties and to construct phylogenetic trees. The phenetic analyses among some of the good fruit quality varieties were conducted using appropriate programs. Thus, clusters including the tested varieties are apparently related according to their date quality. However, Deglet Nour and Kentichi varieties, characterised by their opposite fruit qualities, seem to be dissimilarly related to the others. Our data provides evidence of RAPDs as a powerful technique which may be used to get phenetic information within Tunisian date-palm varieties but does not identify them as monophyletic groups.
\end{abstract}

\section{Phoenix dactylifera / Tunisian date-palms / RAPDs / phylogeny}

Résumé - Analyse des relations phylogénétiques entre des variétés tunisiennes d'une collection de palmier dattier par la technique d'amplification aléatoire de I'ADN polymorphe (RAPD). Des amorces universelles de 10 nucléotides ont été utilisées pour générer des profils d'amplification à partir de quelques variétés. Les profils obtenus montrent la présence de plusieurs marqueurs génétiques discrets. Ces marqueurs, correspondant aux fragments d'ADN amplifiés, ont été utilisés pour évaluer les distances génétiques entre les variétés testées et pour construire des arbres phylogéniques. L'analyse statistique des données a permis de mettre en évidence les relations phylogénétiques entre les variétés caractérisées par leur bonne qualité dattière. La topologie des regroupements ainsi obtenue rappelle celle observée en tenant compte de la qualité des dattes issues des variétés testées. Cependant, les deux variétés Deglet Nour et Kentichi, caractérisées par des qualités dattières opposées, se différencient des autres variétés étudiées. Les résultats montrent clairement que la technique utilisée constitue un outil efficace pouvant être utilisé comme une approche informative des

Communicated by Christian Jung (Kiel, Germany)

* Correspondence and reprints

mokhtar.t@fst.rnu.tn 
relations phylogénétiques qui existent entre les variétés tunisiennes de palmier dattier sans pour autant pouvoir les identifier comme des groupes monophylogénétiques.

\section{Phoenix dactylifera / variétés tunisiennes / RAPDs / phylogénie}

\section{Introduction}

In North Africa, as in several tropical countries, oasis cultures consist of date-palm groves (Phoenix dactylifera $\mathrm{L}$., $2 \mathrm{n}=36$ ), which are major factors of social, environmental and economic stability in these regions. First, date-palms constitute the principal financial resources and food sources of oasis cultivators, and second, it contributes to the development of subjacent cultures (alfalfa, fig trees, pepper, tomato, saffron, etc.). However, most North African date-palm plantations have been seriously threatened for several decades, by a vascular fusariosis (bayoud-disease) due to the fungus Fusarium oxysporum fsp albedinis. In Morocco, as in the West of Algeria, more than 10 million trees have been destroyed so far [8]. Thus, work aiming at the screening of bayoud-resistant varieties with a good date quality is currently in progress aiming at the protection and maintenance of date-palm groves in these countries. Until now, Tunisian plantations appear to have been spared. However, they are continuously menaced by this fusariosis due to its rapid propagation eastwards.

In order to elaborate a preventive fighting strategy for Tunisian date-palm groves, many studies have been developed aiming at the characterization of date-palm varieties. It is noticeable that little has been known about the molecular organization of the date-palm genomics because of a lack of understanding of the genetics of this crop: first, it is a cytogenetically recalcitrant material, second datepalm is a dioecious perennial monocotyledon with long generation times (about 5 years before the first flowering) and third, for centuries emphasis has been based on clonal propagation of noble ecotypes. This reduces the genetic diversity of the cultivars, accelerating their vulnerability to biotic and abiotic stresses. Moreover, attempts to improve knowledge and evaluation of date-palm biodiversity have been reported using either morphological characters or analytic parameters, and have suggested a standard classification of cultivars and ecotypes $[5,14,15]$. Isoenzyme markers have been also evaluated for identification of datepalm genotypes [3, 4]. In addition, data based on molecular markers has proved of some use in datepalm clone identification [2, 6, 7]. However, these were less rewarding because they involved a restricted set of date-palm varieties. Therefore, the development of a large number of molecular markers is needed for sustainable characterisation of cultivars and greater evaluation of genetic diversity in this crop.

Among the strategies that can be used, RAPDs is one of the most powerful and reliable methods [20]. Furthermore, RAPDs have several advantages over isozymes or RFLPs, such as speed, low cost and the use of small amounts of plant material [10]. Also this procedure constitutes a powerful technique to distinguish genotypic variants at the species level and below [9, 18]. In this scope, Sedra et al. [16] have tested the reliability of this procedure as a tool for the identification of Moroccan date-palm cultivars. However, their study included a relatively low number of polymorphic bands of markers. Hence, the phylogenetic relationships were not clearly described.

As part of our work on the improvement of datepalm culture, we became interested in the use of molecular techniques to investigate the polymorphism between and within a wide range of Tunisian date-palm varieties. The DNA polymorphism of Tunisian date-palm varieties was therefore investigated with the help of the RAPD procedure. The purpose of this study was to generate and improve DNA markers that could be scored to examine the phylogenetic relationships in a set of Tunisian date-palm varieties and ecotypes aiming at their molecular characterisation. As a result, anonymous fragments were amplified from 
genomic DNA and were applied to evaluating genetic diversity and relatedness in date-palms.

\section{Materials and methods}

\subsection{Plant material}

We have used a set of eight date-palm varieties listed in Table I. These were chosen for their good fruit quality and are the most common in the main plantation areas which are only located in the South of Tunisia. It is noteworthy that two varieties recently introduced (one from Algeria and one from Iraq) were included. The "Centre de Recherches Phoénicicoles, INRA, Degache, Tunisia" kindly provided the plant material (young leaves). Five to ten plants from each accession were used to obtain RAPD patterns. Date-palm trees were randomly chosen and sampled directly from the oases in the South of Tunisia.

\subsection{DNA preparation}

DNA was prepared from frozen leaves of adult trees. Total cellular DNA was extracted according to Aitchitt et al. [1]. After purification, the resultant DNA was quantified using a Gene-Quant spectrophotometer (Pharmacia), and its integrity was determined after agarose minigel electrophoresis.

\subsection{Primers and RAPD assay}

A large number of decamer random primers, from the following sets of useful items OPA, OPB, OPD and OPM, were used for amplification of date-palm DNA. These primers were screened for suitability on the sampled representative plants from each variety, and varied in their ability to detect polymorphism and in reproducibility.

For PCR, a $25 \mu 1$ reaction mixture was used containing: $20 \mathrm{ng}$ of total cellular DNA, $50 \mathrm{pM}(1 \mu \mathrm{l})$ of primer, $2.5 \mu \mathrm{l}$ of Taq DNA Polymerase reaction buffer, $1.5 \mathrm{U}(0.3 \mu \mathrm{l})$ of Taq DNA Polymerase
Table I. Tunisan date-palm varieties included in the study.

\begin{tabular}{lccc}
\hline Variety name* & Label & Oasis & Origin \\
\hline Deglet Nour & 1 & Tozeur & Tunisia \\
Deglet Bey** & 2 & Degache & Tunisia \\
Boufegous & 3 & Tozeur & Tunisia \\
Ftimi*** & 4 & Djerid & Tunisia \\
Kenta & 5 & Djerid & Tunisia \\
Kentichi & 6 & Djerid & Tunisia \\
Ghars Mtig & 7 & Degache & Algeria \\
Zehdi & 8 & Tozeur & Iraq \\
\hline
\end{tabular}

(*) nomenclature according to Rhouma (1994); (**) and (***) varieties also named Menakher and Alligue.

(Appligène-Oncor, France) and $200 \mathrm{mM}$ of each dNTP (DNA polymerization mix, Pharmacia). The reaction mixture was overlaid with a drop of sterile mineral oil to avoid evaporation. PCR was then performed in a DNA Thermocycler (Bio-med $\mathrm{GmbH}$, Thermocycler 60) using the following cycling parameters: samples were first heated at $94{ }^{\circ} \mathrm{C}$ for 5 minutes before entering a 35 cycles PCR procedure of $94^{\circ} \mathrm{C}$ for 30 seconds, $35{ }^{\circ} \mathrm{C}$ for 1 minute and $72^{\circ} \mathrm{C}$ for 1 minute. A final delay phase of $72^{\circ} \mathrm{C}$ for 5 minutes was always run. To reduce the possibility of cross contamination and variation in the amplification reactions, mastermixes of the reaction constituents were always used. Standardisation between enzyme batches and experiments was ensured by including in each standard controls: a first control consists of reaction mixture excluding any DNA whilst a second was reaction mixture excluding any enzyme and/or primer.

Amplified products were separated electrophoretically on $1.4 \%$ agarose gels in $0.5 \times \mathrm{TBE}$ and detected by staining with ethidium bromide $\left(0.5 \mu \mathrm{g} \cdot \mathrm{ml}^{-1}\right)$. Amplifications were performed at least twice and only reproducible products were taken into account for further data analysis.

\subsection{Data analysis}

For each DNA sample, the presence of each reproducible polymorphic DNA band at a 
particular position on the gels was scored 1, while its absence was denoted by a 0 . RAPD bands were then transformed into a binary character matrix. Data were then computed with the Genedist program (version 3.572c) to produce a genetic distance matrix using the formula of Nei and $\mathrm{Li}$ [12], which assesses the similarity between any two populations on the basis of the number of generated bands. The matrix was then computed with the Neighbour program to produce treefile using the unweighted pair group method with the arithmetic averaging (UPGMA) algorithm [17]. The TreeView program was used to draw phylogenetic diagrams (unrooted tree and cladograms) from the resultant treefile. All these analyses were carried out using appropriate programs in PHYLIP (phylogeny inference package, version $3.5 \mathrm{c}$ kindly provided by Felsenstein, Department of Genetics, University of Washington, Seattle, Wash.) and TreeView (Win32, version 1.5.2) [13].

\section{Results}

Among the seventy tested primers, only thirtyone were used to assess genetic relationships in the tested accessions. These primers which have revealed polymorphic products that were consistently and unambiguously scorable were identified as: OPA-01, OPA-05, OPA-10, OPA-11, OPA-12, OPA-13, OPA-14, OPA-15, OPA-16, OPA-18, OPA-19, OPA-20; OPB-01, OPB-02, OPB-03,
OPB-04, OPB-05, OPB-06, OPB-07, OPB-08, OPB-09, OPB-10, OPB-11, OPB-13, OPB-14, OPB-15, OPB-16; OPD-12, OPD-18; OPM-01 and OPM-05. A total of 392 reproducible polymorphic bands were obtained and scored as RAPD markers. Depending on the DNA template $\times$ primer combination, 5-20 reproducible bands were detected in the 200-2500 bp size range. Thus, maximums of 20 bands were produced when using OPA-12, OPA-16, OPA-19 and OPB-04 primers, however only 5 amplified fragments were obtained with OPA-07 primer. As shown in Figure 1, RAPD banding patterns were typically generated from the included varieties. In these cases OPA-01, OPB-01, OPD-18, and OPM-05 were used to amplify DNA from the eight accessions.

A distance matrix between varieties (Tab. II) shows an average distance range from 0.4183 to 0.9087 with a mean of 0.6826 . Thus, the accessions tested in this study are highly divergent at the DNA level. The smallest distance value was observed between Boufegous and Deglet Bey varieties $(0.4183)$ which appear to be the most similar varieties and can be closely regrouped. The maximum distance value of 0.9087 , indicating a great dissimilarity, is observed between the Kentichi and Ghars Mtig varieties. All the other varieties display different intermediate levels of similarity and are grouped with the other ones. It is noteworthy that the Deglet Nour variety presented very limited average distance ranges (from 0.6434 to 0.7037 ) with the other ones except with Kentichi. Thus,

Table II. Genetic distances matrix among a subset of Tunisian date-palm elite varieties, based on RAPD data and computed using the formula of Nei and Li.

\begin{tabular}{lccccccc}
\hline Variety & Deglet Nour & Deglet Bey & Boufegous & Ftimi & Kenta & Kentichi & Ghars Mtig Zehdi \\
\hline Deglet Nour & 0.0000 & & & & & & \\
Deglet Bey & 0.7037 & 0.0000 & & & & & \\
Boufegous & 0.6931 & 0.4183 & 0.0000 & & & & \\
Ftimi & 0.6931 & 0.7563 & 0.7348 & 0.0000 & & & \\
Kenta & 0.6630 & 0.7563 & 0.6531 & 0.7242 & 0.0000 & & 0.0000 \\
Kentichi & 0.8414 & 0.5375 & 0.5731 & 0.6983 & 0.8065 & 0.0000 & 0.0000 \\
Ghars Mtig & 0.6780 & 0.7190 & 0.6483 & 0.6282 & 0.5731 & 0.9087 & 0.6881 \\
Zehdi & 0.6434 & 0.7348 & 0.6830 & 0.6053 & 0.6434 & 0.680 & 0.0000 \\
\hline
\end{tabular}


Deglet Nour could be characterized by a slight divergence at the DNA level and could be unlikely regrouped with the other clusters.

The genetic distance matrix using the UPGMA algorithm was computed to cluster the data and to draw the precise relationships between the eight tested genotypes. The resultant phenogram shown in Figure 2, illustrates the divergence between the used varieties and suggests their tree branching. The clusters identified significantly supported a
OPA-01

$\mathrm{kb} \quad \mathrm{M} 1234 \mathrm{C5} 678$

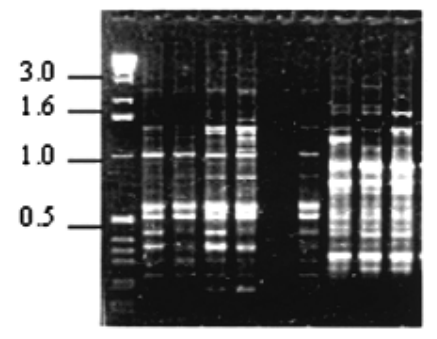

OPB-01

$\mathrm{kb} \quad \mathrm{M} 12345 \mathrm{C} 678$
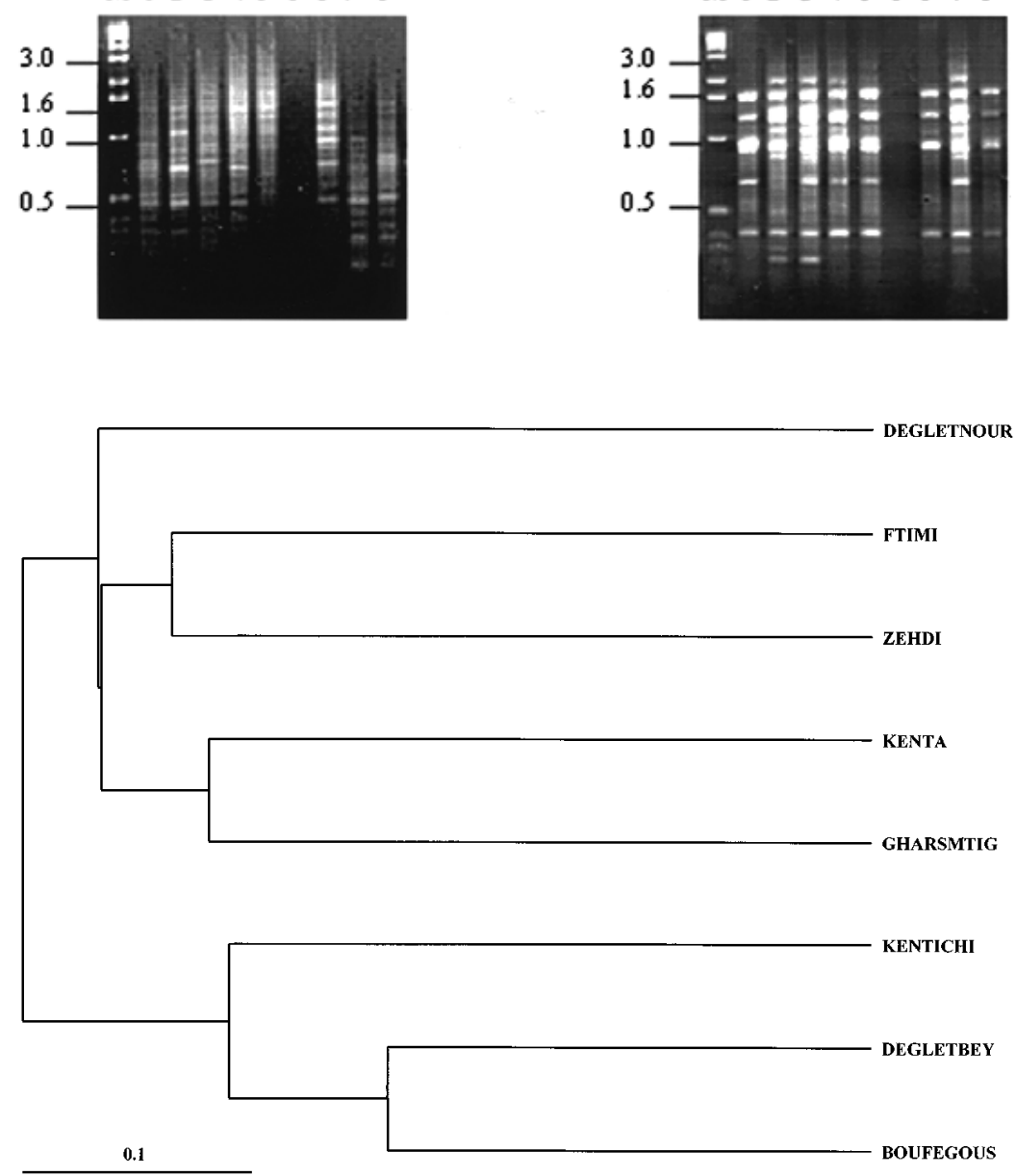

OPM-05

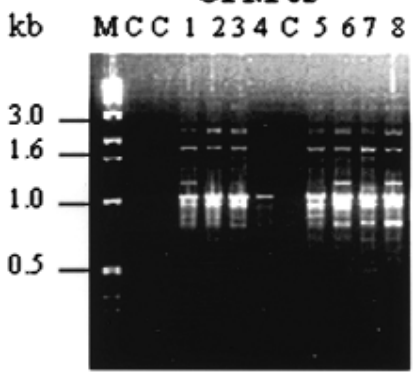

OPD-18

$\mathrm{kb} \quad \mathrm{M} 12345 \mathrm{C} 678$

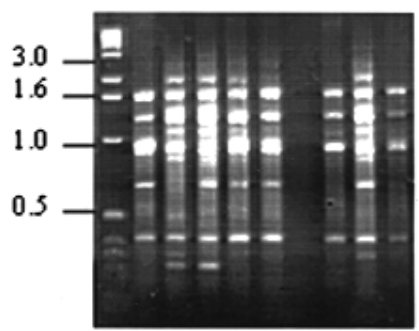

Figure 1. Examples of DNA polymorphisms detected among Tunisian datepalm accessions using different universal primers. M: Standard molecular size marker (1 kb Ladder, Gibco-BRL); lanes C: controls included, lanes (1-8) accessions described in materials and methods. See Table I for variety labels.
Figure 2. Dendrogram of a subset of Tunisian date-palm varieties constructed from Nei and Li's genetic distance matrix estimated from RAPD data and clustered with the UPGMA. Each arm of the tree corresponds to the scaled genetic distance. 
varietal branching of only two varieties. These are Deglet Nour and Kentichi which are characterised by their opposite date property: dates issued from Deglet Nour are unctuous against dry fruits from Kentichi [15]. Thus, it has been assumed that the following varieties: Boufegous-Deglet Bey, KentaGhars Mtig and Ftimi-Zehdi varieties may constitute paired clusters, while Deglet Nour and Kentichi varieties may be carefully considered as two single varietal groups with respect to the other clusters. So far, Deglet Nour seems to be regrouped with clusters composed with Kenta and Ghars Mtig or Ftimi and Zehdi varieties. The Kentichi variety seems to be most closely regrouped with the Deglet Bey and Boufegous cluster.

\section{Discussion}

The aim of the present study was to provide polymorphic DNA markers suitable for examination of the phylogenetic relationships among a set of Tunisian date-palm varieties with the help of RAPD technology. As a result of our investigation, we may expect that the subsequent banding patterns computed using appropriate programs, would be useful for the establishment of phylogenetic relationships among a set of high quality fruit varieties. Our data provides evidence of divergence between Tunisian varieties that are organized in clusters. However, we are unable to identify all the tested genotypes as monovarietal groups. In addition, it has been assumed that foreign varieties (i.e. Ghars Mtig and Zehdi) recently introduced to Tunisian groves are closely regrouped with indigenous ones. These varieties may be unlikely clustered with any other group during their adaptation process in the new cultural context. At least two reasons could be put forward to explain these results. The first one would be the presence of a common genetic origin among the tested varieties in spite of their great diversity. This consideration is strongly supported by the ancient Mesopotamian (fertile crescent) origin of the date-palms domestication $[11,21]$. According to the second, such results could be related to several problems that may arise in the RAPD approach, mainly reported by Stammers et al. [19], particularly the phenomenon of homoplasy or convergence. However, these authors have reported that the use of RAPD for phylogenetic inference is only likely to be an appropriate approach for closely related groups. Hence, in the case of date-palm varieties, our data suggests that RAPD can reliably estimate relationships among varieties on the basis of their overall similarity and does not reflect evolutionary pathways.

It is worth noting that data analysis using either the formula of Cavalli-Sforza or the other appropriate programs included in the PHYLIP package (i.e. Dollop, Dolpenny, Mix and Penny programs) have generated unrooted trees and cladograms which are nearly identical to those based on the formula of Nei and Li, and differ only in the placement of the clusters cited above (data not shown). Hence, the close agreement of both analyses may indicate that RAPD banding patterns may be genetically informative of the tested varieties. These patterns permit only the analysis of the DNA divergence and the phylogenetic construction among Tunisian date-palm varieties. On the whole, the varieties' relationships based on the molecular data concur in some cases with the groupings based on the high degree of the variation observed for several agronomic traits particularly related with the fruits produced by each variety. This is well exemplified in the case of Boufegous and Deglet Bey varieties clustered together, which produce dates currently characterised by a relatively big size and similar flavour and colour qualities. On the other hand, the organization deduced from the RAPD markers' analysis is in agreement with previous molecular studies [16]. These authors showed that morphologically similar varieties are associated together and observed that cultivars originated from Tunisia and Iraq did not exhibit a separation from the Moroccan ecotypes suggesting a narrow genetic diversity of date-palms.

Opportunely, the present work provides evidence that the RAPD method constitutes an alternative strategy to precisely assess the phylogenetic relationships between a set of Tunisian date-palm varieties. It is obviously necessary to enlarge both the number of varieties and/or the number of 
primers to obtain a deeper insight of Tunisian datepalm varieties. A prerequisite for achieving this work is the improvement of reliable molecular markers that make possible discrimination between genotypes. A search is currently in progress to molecularly characterise these varieties as a shortterm step and to provide molecular markers related to bayoud-disease as a long-term step.

Acknowledgements. The authors wish to thank the staff of CRP Degache for providing plant material; Prof. J.C. Mounolou and Prof. B. Lejeune (Univesité Paris Sud, France) for stimulating discussions. This work is supported by grants from the Direction Générale de la Recherche Scientifique (Ministère de l'Enseignement Supérieur), the Secrétariat d'État à la Recherche Scientifique et à la Technologie and the Institut Français de Coopération: Projet CMCU F96/0911 (Ambassade de France en Tunisie).

\section{References}

[1] Aitchitt M., Ainsworth C.C., Thangavelu M., A rapid and efficient method for the extraction of total DNA from mature leaves of date palm (Phoenix dactylifera L.), Plant Mol. Biol. Report. 11 (1993) 317-319.

[2] Aitchitt M., Mantell S.H., Thangavelu M., Ainsworth C.C., Cloning date palm (Phoenix dactylifera L.) DNA and characterization of low, medium and high DNA sequences, Elaeis 7 (1995) 57-63.

[3] Bendiab K., Baaziz M., Brakez Z., Sedrea My.H., Correlation of isoenzyme polymorphism and bayoud disease resistance in date palm cultivars and progeny, Euphytica 65 (1993) 23-32.

[4] Bennaceur M., Lanaud C., Chevalier M.H., Bounaga N., Genetic diversity of date palm (Phoenix dactylifera $\mathrm{L}$.) from Algeria revealed by enzyme markers, Plant Breed. 107 (1991) 56-69.

[5] Bouabidi H., Reynes M., Rouissi M.B., Critères de caractérisation des fruits de quelques cultivars de palmiers dattiers (Phoenix dactylifera L.) du sud Tunisien, Ann. Inst. Nat. Rech. Agr. Tun. 69 (1996) 73-87.

[6] Cornicquel B., Mercier L., Date-palm (Phoenix dactylifera L.) cultivar identification by RFLP and RAPD, Plant Sci. 101 (1994) 163-172.

[7] Cornicquel B., Mercier L., Identification of date palm (Phoenix dactylifera L.) cultivars by RFLP: partial characterization of a cDNA probe that contains a sequence encoding a zinc finger motif, Int. J. Plant Sci. 158 (1997) 152-156.

[8] Haddouch M., Situation actuelle et perspectives de développement du palmier dattier au Maroc, Options Mediterr. 28 (1996) 63-79.

[9] He G., Prakach C.S., Jarret R.L., Analysis of genetic diversity in sweetpotato (Ipomea batatas) germplasm collection using DNA amplification fingerprinting, Genome 38 (1995) 938-945.

[10] Koch G., Jung C., Phylogenetic relationships of industrial chicory varieties revealed by RAPDs and AFLPs, Agronomie 17 (1997) 323-333.

[11] Munier P., Le problème de l'origine du palmier dattier et l'Atlantide, Fruits 29 (1974) 235-240.

[12] Nei M., Li W.H., Mathematical models for studying genetic variation in terms of restriction endonucleases, Proc. Nat. Acad. Sci. USA 76 (1979) 5269-5273.

[13] Page R.D.M., http//:taxonomy.zoology. gla.ac.uk/rod./rod.html, 1998.

[14] Reynes M., Bouabidi H., Piombo G., Risterucci A.M., Caractérisation des principales variétés de dattes cultivées dans la région du Djérid en Tunisie, Fruits 49 (1994) 189-298.

[15] Rhouma A., Le palmier dattier en Tunisie. I : Le patrimoine génétique, Arabesque, Tunis, Tunisie, 1994.

[16] Sedra My.H., Lashermes P., Trouslot P., Combes M.C., Hamon S., Identification and genetic diversity analysis of date-palm (Phoenix dactylifera L.) varieties from Morocco using RAPD markers, Euphytica 103 (1998) 75-82.

[17] Sneath P.H.A., Sokal R.R., Numerical taxonomy, Freeman, San Francisco, USA, 1973.

[18] Soltis P.S., Soltis D.E., Doyle J.J., Molecular systematics of plants, Chapmann and Hall, New York, USA, 1992.

[19] Stammers M., Harris J., Evans G.M., Hayward M.D., Forster J.W., Use of random PCR (RAPD) technology to analyse phylogenetic relationships in the Lolium/Festuca complex, Heredity 74 (1995) 19-27.

[20] Williams G.K., Kubelik A.R., Livak K.J., Rafalski J.A., Tingey S.V., DNA polymorphisms amplified by arbitrary primers are useful as genetic markers, Nucl. Acid Res. 18 (1990) 6531-6535.

[21] Wrigley G., Date-palm (Phoenix dactylifera L.), in: Smartt J., Simmonds N.W. (Eds.), 2nd ed., The evolution of crop plants, Longman, Essex, United Kingdom, 1995, pp. 399-403. 